\title{
Counteracting domestic violence against elders in the professional practice of a nurse employed in the primary health care system
}

Przeciwdziałanie przemocy domowej względem seniora w praktyce pielęgniarki podstawowej opieki zdrowotnej

\section{Agnieszka Kotarba' , Adrianna Maciaszek², Ewa Borowiak}

\author{
'Zakład Pedagogiki w Pielęgniarstwie, Wydział Nauk o Zdrowiu, Uniwersytet Medyczny w Łodzi/ \\ Department of Nursing Pedagogics, Faculty of Health Sciences, Medical University of Lodz \\ ${ }^{2}$ Magistrantka w Zakładzie Pedagogiki w Pielęgniarstwie, Wydziału Nauk o Zdrowiu, Uniwersytetu Medycznego w Łodzi/ \\ Department of Nursing Pedagogics, Faculty of Health Sciences, Medical University of Lodz \\ 3Zakład Pielęgniarstwa Zachowawczego, Wydział Nauk o Zdrowiu, Uniwersytet Medyczny w Łodzi/ \\ Department of Conservative Nursing, Faculty of Health Sciences, Medical University of Lodz
}

Agnieszka Kotarba: 0000-0002-0755-3172 Ewa Borowiak: 0000-0003-1790-3516

CORRESPONDING AUTHOR/AUTOR DO KORESPONDENCJI: Agnieszka Kotarba Zakład Pedagogiki w Pielęgniarstwie, Uniwersytet Medyczny w Łodzi ul. Jaracza 63, 90-251 Łódź e-mail: agnieszka.kotarba@umed.lodz.pl OPIEKI ZDROWOTNEJ

Cel pracy. 0cena przygotowania pielęgniarki podstawowej opieki zdrowotnej do realizowania profilaktyki przemocy domowej względem seniora.

Materiał i metody. Materiał zebrano w grupie 70 pielęgniarek. Dobór próby był celowy - pielęgniarki pracujące w strukturach miejskiego centrum medycznego $w$ Łodzi. Kryterium włączenia do grupy była zgoda respondentki i zatrudnienie na stanowisku pielęgniarki podstawowej opieki zdrowotnej. W badaniach zastosowano metodę sondażu diagnostycznego, z użyciem kwestionariusza własnej konstrukcji. Uzyskane wyniki badań poddano analizie statystycznej.

Wyniki. Zdaniem pielęgniarek do istotnych czynników utrudniających im realizowanie profilaktyki przemocy względem seniora należy brak skutecznych narzędzi do udzielania pomocy poszkodowanym. Analiza wariancji ujawniła związek między opinią pielęgniarek odnośnie profilaktyki przemocy w rodzinie względem seniora a ich wykształceniem, stażem pracy oraz w obrębie poszczególnych przekonań.

Wnioski. Przemoc względem seniora jest problemem globalnym i narastającym. Polskie pielęgniarki mają ustawowy obowiązek podejmowania interwencji w celu przeciwdziałania przemocy w rodzinie. Pielęgniarki podstawowej opieki zdrowotnej nie są przygotowane do realizowania profilaktyki przemocy domowej względem seniora. Istnieje potrzeba doskonalenia podyplomowego pielęgniarek podstawowej opieki zdrowotnej z zakresu profilaktyki przemocy domowej.

Słowa kluczowe: pielęgniarka, profilaktyka przemocy domowej, senior

\section{COUNTERACTING DOMESTIC VIOLENCE AGAINST ELDERS IN THE PROFESSIONAL PRACTICE OF A NURSE EMPLOYED} IN THE PRIMARY HEALTH CARE SYSTEM

Aim. Assessment of preparation of a nurse - employee of the primary health care for providing preventative measures against domestic violence targeted at elders.

Material and methods. The material was collected in a group of 70 nurses - employees of the primary health care of a medical centre in Lodz. Inclusion criteria were: the respondent's consent for the inclusion in the study and the position of a nurse of the primary health care system. The authors of the study used the diagnostic survey method, with the application of their own questionnaire. Obtained results were statistically analysed.

Results. In the nurses' opinion, lack of knowledge of effective tools, which could be used to provide victims with help, considerably hampers implementation of preventive measures for counteracting domestic violence. A multivariate analysis revealed a relationship between the opinion of nurses on prevention of domestic violence against the elderly and their education, the number of years worked and individual beliefs. 
Conclusions. Violence against elders is a growing global problem. Polish nurses are legally obliged to initiate interventions in order to counteract domestic violence. Nurses from the primary health care are not prepared to carry out prevention of violence against the elderly. There is a need to provide nurses employed in the primary health care with post-graduate training on counteracting domestic violence against the elderly.

\section{INTRODUCTION}

Domestic violence against elders is considered a global and growing problem which should lie in the interest of the health care system. In order to resolve it, we must make efforts to increase the effectiveness of prevention programmes [1]. It is predicted that due to rapid aging of the world population, the number of victims of violence among elderly people will increase to 320 million in 2050 [2]. The World Health Organization warns that $10 \%$ of the senior population in developed countries are affected by domestic violence [3]. According to current Polish legal acts, health care employees are responsible for counteracting domestic violence and they take action against it within their official duties $[4,5]$. The type and scope of intervention is specified in the regulation on the „Blue Card" procedure [5]. The specificity of nursing practice in the primary health care system and, above all, providing the patient with „nursing care” [6] in his/her living environment, enables the nurse to identify people affected by domestic violence, take interventions and provide adequate support to the victims.

\section{AIM}

The aim of the study was to evaluate the readiness of a nurse of the primary health care system to get involved in prevention of domestic violence against the elderly.

\section{MATERIALS AND METHODS}

The material was collected in a group of 70 nurses. The nurses were not randomly selected; they were employees of a city medical centre in Łódź. Criteria of inclusion in the study group were the following: holding the position of a nurse of primary health care and a consent given by the surveyee to be included in this study. The study meets requirements of the Helsinki Declaration. In the talk with the surveyor, the respondents were informed that the study would be anonymous and they would have a right to withdraw from it at any stage. In order to assess the variables, the authors used the diagnostic survey method as well as their own questionnaire which included the respondent's particulars and score and questions on the opinion of nurses on the prevention of domestic violence against elders, at the level of primary health care institutions.

Statistical analysis. The variables were analysed with the use of one-way analysis of variance (ANOVA), the Kruskal-Wallis test, the chi square test and the Pearson and Spearman correlation coefficient. The quantitative variables are presented as mean \pm standard deviation. The $p$ value $<0.05$ was assumed to be statistically significant. Obtained results were subject to a statistical analysis using the Statistica 12 PL programme.

\section{RESULTS}

\section{Characteristics of the respondents}

An analysis of the results revealed that a typical nurse of the primary health care system is a woman (the entire cohort), a resident of a large city ( 0.78 fractions), aged $52.38 \pm 8.38$ years, who lives in a cohabiting relationship ( 0.58 fractions), has two children $(\mathrm{SD}=1.61)$ and her current workplace is not her first one (0.8 fractions) and not the only one ( 0.74 fractions). Besides, she has secondary education (0.74 fractions), at least twenty-year professional experience $27.61 \pm 9.13$, including experience gained in primary health care institutions $12.17 \pm 10.45$, has no nursing specialization ( 0.8 fractions) and has not completed any vocational qualification courses ( 0.68 fractions).

\section{Opinion of primary health care nurses on the prevention of domestic violence against elders in their professional practice}

In the analysed group of nurses, less respondents think that domestic violence against elders is a significant problem (0.4 fractions). Similarly, a smaller percentage of the respondents ( 0.38 fractions) claimed that elders are particularly threatened with violence. Less than half of the respondents ( 0.47 fractions) believes that prevention carried out by a primary health care nurse definitely reduces violence against elders. The surveyed nurses also claimed that in their work they do not encounter elderly victims of domestic violence ( 0.57 fractions). What is significant is the fact that respondents constituting 0.15 fractions did not explicitly express their opinion on this issue. The majority of respondents (0.9 fractions) stated that a primary health care nurse does not have adequate tools to help victims of domestic violence. When asked about the forms of optimizing violence prevention at the level of primary health care, the majority of respondents pointed out professional psychological help for patients (Figure 1).

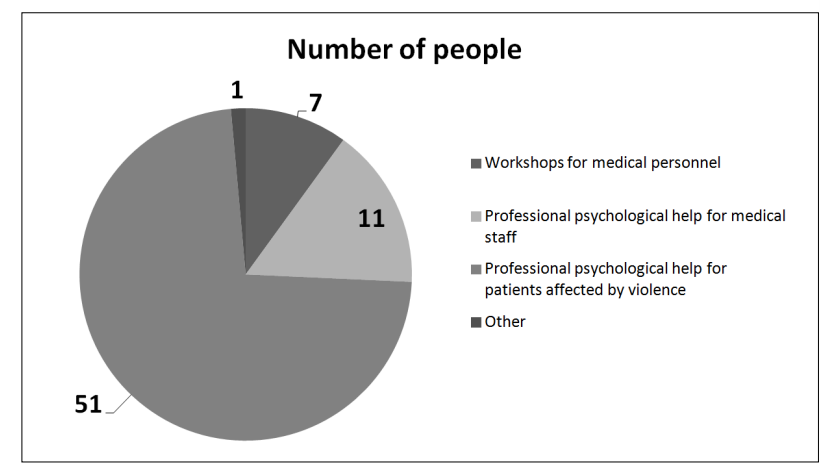

Fig. 1. Senior's opinion on the forms of optimizing the prevention of violence at the primary health care level 
A multivariate analysis revealed a relationship between the opinion of nurses on prevention of domestic violence against the elderly and their education, the number of years worked and individual beliefs. A positive correlation was observed with regards to education $\left(\mathrm{Chi}^{2}=10.18\right.$; $\mathrm{p}=0.04)$, specialization $\left(\mathrm{Chi}^{2}=7.98 ; \mathrm{p}=0.02\right)$ and the opinion that elders are particularly threatened with violence (Figure 2).

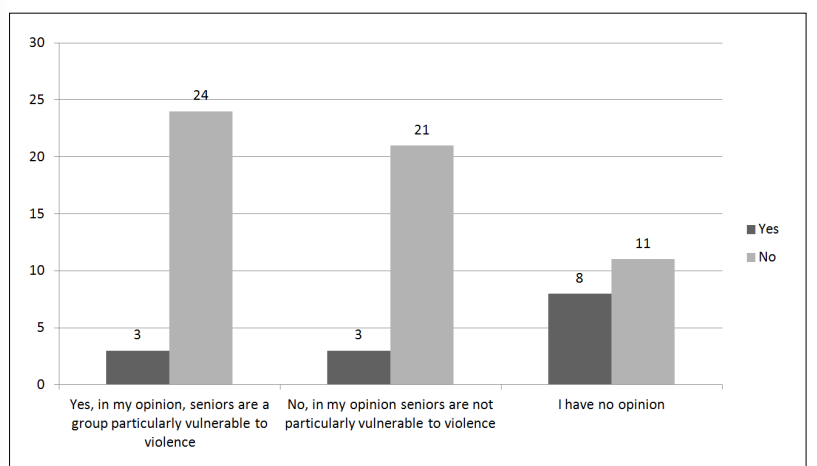

Fig. 2. Nurses' specialization and the belief that seniors are a group of patients who are particularly vulnerable to violence

At the same time, this opinion is accompanied by a belief that prevention carried out by primary health nurse really reduces violence against seniors $\left(\mathrm{Chi}^{2}=13.31\right.$; $\mathrm{p}=0.009$ ). It is also accompanied by a contact in the professional practice with elders who are victims of domestic violence $\left(\mathrm{Chi}^{2}=10.79 ; \mathrm{p}=0.03\right)$. It was also observed that selection of methods of optimizing prevention of violence against elders by primary health care nurses depends on the number of years of professional experience $(\mathrm{F}=3.03$; $\mathrm{p}=0.03$ ). Respondents who have worked for less than twenty years recommend that nurses be provided with training, whereas respondents with more than twenty years of professional experience suggest that not only victims of domestic violence but also medical personnel who intervenes in defence of those victims should be provided with psychological help.

\section{DISCUSSION}

Elders, apart from people with disabilities and children, are particularly threatened with violence. It results from, among others, reduced psychobiological abilities, numerous dysfunctions of the body, isolation and progressive dependence on the surroundings. Data indicate that in most cases, people living nearby, i.e. children, spouses, grandchildren appear to be perpetrators of violence $[7,8,9]$. Studies conducted by the Polish Academy of Sciences indicate that domestic violence against the elderly is widespread and it is systematically increasing. The report also reveals that the most frequently reported forms of violence in recent years include: isolation, jerking (15.7\%), taking away money (20.4\%) and teasing about disability (18.8\%) [7]. The widespread phenomenon of domestic violence against the elderly is not typical of Polish families only; no less shocking attitude towards elders can be observed in other European Union countries, Russia or the US [10]. In the light of these data, the results of the authors' study are alarming because they are unusually optimistic. In the opinion of almost 3/4 of the respondents, elders are not particularly threatened with violence. Besides, in their professional practice, the surveyees neither did not encounter an elderly person who could be considered a victim of domestic violence nor they were not able to clearly define the phenomenon of violence. Different results were obtained in a study conducted on a group of 295 nurses and midwives participating in postgraduate training [11]. Most of the respondents $(81.7 \%)$ stated that they observed incidences of domestic violence against elders while performing their job duties. Of those respondents, nurses rather than midwives significantly more often stated they witnessed domestic violence $(\mathrm{p}<0.001)$. Some nurses claimed to have observed violent behaviours more than once. Other authors also confirm that nurses encountered patients-victims of domestic violence more frequently than in the presented study $[11,12,13]$. It should be assumed that nurses' opinions and beliefs as well as the way in which they perceive the phenomenon of domestic violence depend on their education level. When it comes to $1 / 4$ of the respondents, they have university education, $1 / 5$ hold medical specialisations and almost $1 / 3$ completed qualification courses. In their own study, the authors observed a relationship between pre- and postgraduate education, the number of years worked and nurses' opinions regarding various forms of prevention of domestic violence against elders. We can conclude that university education and/or participation in various forms of postgraduate training allow to gain knowledge and skills necessary to implement prevention of domestic violence. Results of this study correspond to results obtained by other authors $[1,14,15,16]$ who not only confirm a relationship between the level of education of nurses and their knowledge of domestic violence (i.e. forms, symptoms, tools necessary to implement prevention), but also point out that education and information support, provided to health care personnel, are the grounds for their effective intervention and proper identification of violence against elders.

Motivation and possibilities of nurses to participate in post-graduate training are a different issue. The results of research conducted for years suggest that a significant obstacle in raising qualifications are financial costs and the lack of significant impact of training on the salary or promotion of nurses $[17,18,19]$. The results of research conducted for years suggest that a significant obstacle in raising qualifications are financial costs and the lack of significant impact of training on the salary or promotion of nurses. According to the authors, the primary health care system should develop systemic solutions that will enable nurses to participate in trainings on prevention of domestic violence, that will monitor these trainings and then adapt them to nurses' real work and life. There are similar expectations regarding the selection of forms optimizing the implementation of prevention of domestic violence against elders. In this study, nurses actually revealed a need for professional psychological support. Those with a smaller number of worked years pointed out a need for professional trainings, whereas those with longer work experience claimed that not only victims of 
domestic violence but also medical personnel who intervenes in defence of those victims should be provided with psychological help. This issue also requires systemic solutions which however cannot be presented at length in this study. It can only be said that "the helping person himself or herself requires help", which is related to prevention in the area of professional burnout in nurses.

\section{CONCLUSIONS}

1. Violence against elders is a growing global problem.

2. Polish nurses are legally obliged to initiate interventions in order to counteract domestic violence.

3. Nurses from the primary health care are not prepared to carry out prevention of violence against the elderly.

4. There is a need to provide nurses employed in the primary health care with post-graduate training on counteracting domestic violence against the elderly.

\section{Przeciwdziałanie przemocy domowej względem seniora w praktyce pielęgniarki podstawowej opieki zdrowotnej}

\section{WPROWADZENIE}

Przemoc wobec seniora jest uznawana na arenie międzynarodowej za globalny i narastający problem, który wymaga uwagi systemu opieki zdrowotnej i podjęcia wysiłku w celu zwiększenia skuteczności programów profilaktycznych [1]. Przewiduje się, że z powodu gwałtownego starzenia się światowej populacji, liczba ofiar przemocy wśród osób starszych wzrośnie w roku 2050 do 320 milionów [2]. Światowa Organizacja Zdrowia alarmuje, że przemocą domową $\mathrm{w}$ krajach rozwiniętych jest dotkniętych $10 \%$ populacji seniorów [3]. Zgodnie z obowiązującymi w Polsce aktami prawnymi przeciwdziałanie przemocy w rodzinie jest działaniem podejmowanym w ramach obowiązków służbowych przez pracowników ochrony zdrowia [4,5] a rodzaj i zakres interwencji precyzuje rozporządzenie w sprawie procedury „Niebieskiej Karty” [5]. Specyfika praktyki pielęgniarskiej w POZ (Podstawowej Opiece Zdrowotnej) a przede wszystkim otaczanie „pielęgniarską troską” [6] pacjenta w jego środowisku życia, daje pielęgniarce szczególną możliwość do identyfikowania osób dotkniętych przemocą domową, podejmowania oddziaływań interwencyjnych oraz udzielania adekwatnego wsparcia poszkodowanym.

\section{CEL PRACY}

Celem badań była ocena przygotowania pielęgniarki podstawowej opieki zdrowotnej do realizowania profilaktyki przemocy domowej względem seniora.

\section{MATERIAŁ I METODYKA}

Materiał zebrano w grupie 70 pielęgniarek. Dobór próby był celowy - pielęgniarki pracujące w strukturach miejskiego centrum medycznego w Łodzi. Kryterium włączenia do grupy stanowiło zatrudnienie na stanowisku pielęgniarki podstawowej opieki zdrowotnej oraz zgoda ankietowanej na udział w badaniu. Badanie spełnia wymogi Deklaracji Helsińskiej, respondentki podczas bezpośredniego kontaktu $\mathrm{z}$ ankieterem, zostały poinformowane o anonimowości badania oraz o możliwości rezygnacji na każdym etapie jego trwania. Do oceny zmiennych zastosowano metodę sondażu diagnostycznego, z użyciem kwestionariusza własnej konstrukcji, w którym zawarto metryczkę i pytania odnoszące się do opinii pielęgniarek na temat profilaktyki przemocy domowej względem seniora realizowanej, na poziomie placówek POZ.

Analiza statystyczna. Zmienne analizowano przy pomocy jednoczynnikowej analizy wariancji (ANOVA), testów: Kruskala-Wallisa, chi ${ }^{2}$ oraz współczynnika korelacji Pearsona i Spearmana. Zmienne ilościowe przedstawiono jako średnią \pm odchylenie standardowe. Za poziom istotny statystycznie przyjęto wartość $p<0,05$. Uzyskane wyniki poddane zostały analizie statystycznej przy użyciu programu Statistica 12 PL.

\section{WYNIKI BADAŃ}

\section{Charakterystyka respondentów}

Analiza wyników wskazuje, że reprezentatywna dla próby pielęgniarka podstawowej opieki zdrowotnej jest kobietą (cała kohorta), mieszkanką dużego miasta $(0,78$

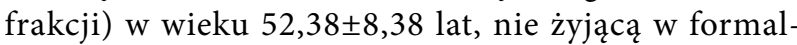
nym związku (0,58 frakcji), posiadającą dwoje dzieci $(\mathrm{SD}=1,61)$. Dla której obecna praca nie jest pierwszym $(0,8$ frakcji) ani jedynym miejscem zatrudnienia $(0,74$ frakcji). Typowa respondentka legitymuje się wykształceniem średnim (0,74 frakcji), ma ponad dwudziestoletni staż pracy $27,61 \pm 9.13 \mathrm{w}$ tym w strukturach POZ $12,17 \pm 10,45$ lat, nie posiada specjalizacji pielęgniarskiej $(0,8$ frakcji) oraz nie ma ukończonego kursu kwalifikacyjnego (0,68 frakcji).

\section{Opinia pielęgniarek podstawowej opieki zdrowotnej na temat profilaktykí przemocy domowej względem seniora w ich praktyce zawodowej}

$\mathrm{W}$ analizowanej grupie pielęgniarek mniejszość stanowią respondentki zdaniem, których przemoc w rodzinie względem seniora jest istotnym problemem $(0,4$ frakcji). Podobnie mniejszy odsetek ankietowanych (0,38 frakcji) ocenił, że seniorzy należą do grupy osób szczególnie 
narażonych na przemoc. Mniej niż połowa badanych $(0,47$ frakcji) jest przekonana, że profilaktyka realizowana przez pielęgniarkę na poziomie POZ ma realny wpływ na ograniczenie przemocy względem seniora. Ankietowane pielęgniarki oceniły również, że w swojej pracy nie spotykają się z seniorami - ofiarami przemocy w rodzinie $(0,57$ frakcji) co istotne 0,15 frakcji nie wypowiedziało się jednoznacznie w tym zakresie. W opinii większości respondentek (0,9 frakcji), pielęgniarka podstawowej opieki zdrowotnej nie dysponuje odpowiednimi narzędziami do udzielania pomocy ofiarom przemocy w rodzinie. Na pytanie dotyczące form optymalizowania profilaktyki przemocy na poziomie POZ, większość ankietowanych wskazała na profesjonalną pomoc psychologiczną dla pacjentów (Ryc.1).

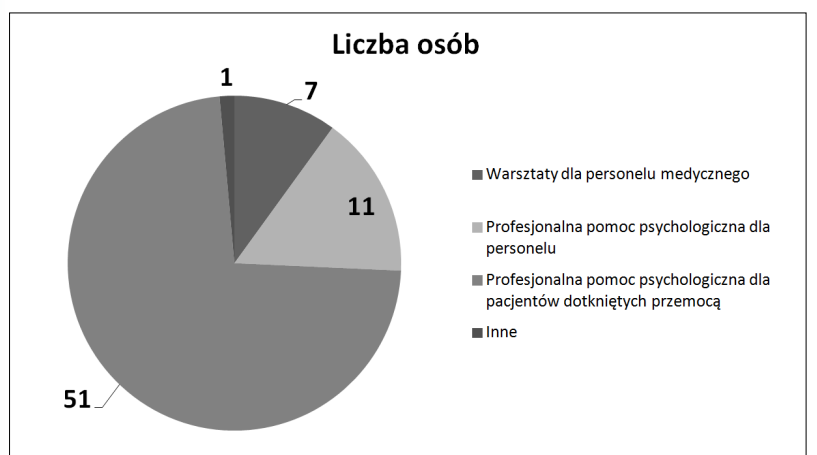

Ryc. 1. Opinia na temat form optymalizowania profilaktyki przemocy wg. seniora na poziomie $\mathrm{POZ}$

Analiza wariancji ujawniła związek między opinią pielęgniarek odnośnie profilaktyki przemocy w rodzinie względem seniora a ich wykształceniem, stażem pracy oraz w obrębie poszczególnych przekonań. Zidentyfikowano pozytywną korelację między wykształceniem $\left(\mathrm{Chi}^{2}=10,18 ; \mathrm{p}=0,04\right)$, specjalizacją $\left(\mathrm{Chi}^{2}=7,98 ; \mathrm{p}=0,02\right)$ a przekonaniem, że seniorzy są grupą pacjentów szczególnie narażoną na przemoc (Ryc.2).

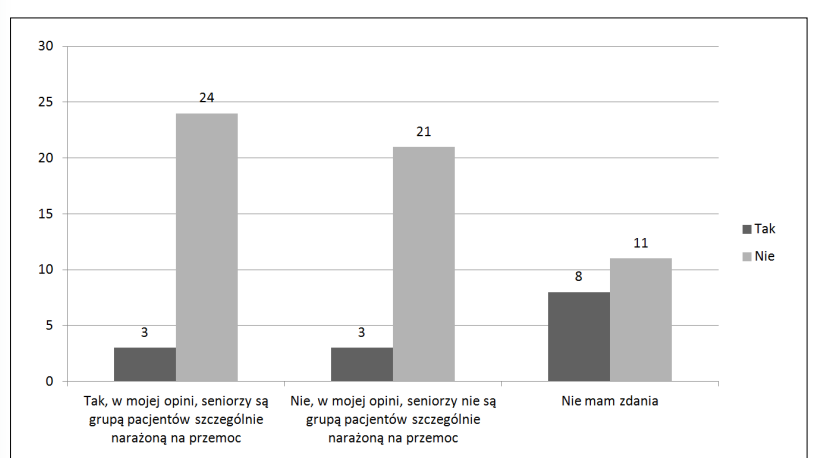

Ryc. 2. Posiadanie przez pielęgniarki specjalizacji a przekonanie, że seniorzy są grupą pacjentów szczególnie narażoną na przemoc

Przy czym to przekonanie współwystępuje z opinią dotyczącą wpływu profilaktyki realizowanej przez pielęgniarkę POZ na realne ograniczenie przemocy względem seniora $\left(\mathrm{Chi}^{2}=13,31 ; \mathrm{p}=0,009\right)$ i kontaktem $\mathrm{w}$ ramach praktyki zawodowej $\mathrm{z}$ seniorami-ofiarami przemocy domowej $\left(\mathrm{Chi}^{2}=10,79 ; \mathrm{p}=0,03\right)$. Zaobserwowano ponadto, że staż zawodowy różnicuje przekonania pielęgniarek POZ na temat form optymalizowania realizowanej przez nie profilaktyki przemocy względem seniora $(F=3,03$; $\mathrm{p}=0,03$ ). Osoby ze stażem zawodowym poniżej 20 lat, wskazują na szkolenia dla pielęgniarek, natomiast respondentki z ponad dwudziestoletnim stażem proponują objąć profesjonalną opieką psychologiczną ofiary przemocy, jak i personel ochrony zdrowia, który interweniuje na rzecz pacjenta-ofiary przemocy domowej.

\section{DYSKUSJA}

Seniorzy, obok osób niepełnosprawnych i dzieci należą do grupy szczególnie narażonej na przemoc. Wynika to m.in. ze zmniejszonych możliwości psychobiologicznych, licznych dysfunkcji organizmu, izolacji oraz postępującej zależności od otoczenia. Dane wskazują, że najczęściej sprawcami przemocy są osoby $z$ najbliższego środowiska rodzinnego tj. dzieci, współmałżonek, wnuki $[7,8,9]$. Badania Polskiej Akademii Nauk pokazują, że przemoc w rodzinie wobec osób starszych jest rozpowszechniona i odnotowuje się systematyczny wzrost jej natężenia. Raport ujawnia również, że do najczęściej relacjonowanych w ciągu ostatnich lat form przemocy należą: izolowanie i szarpanie (po 15,7\%), zabieranie pieniędzy $(20,4 \%)$ i wytykanie niepełnosprawności (18,8 \%) [7]. Rozpowszechnienie i natężenie poszczególnych rodzajów przemocy domowej wobec osoby starszej nie jest specyfiką polskich rodzin, nie mniej szokujące dane pochodzą z terenu innych krajów Unii Europejskiej, Rosji czy USA [10]. W kontekście tych danych wyniki badań własnych budzą niepokój, są bowiem nierealnie optymistyczne. Niemal 3/4 ankietowanych oceniło, że seniorzy nie należą do grupy pacjentów szczególnie narażonych na przemoc oraz, że w swojej praktyce zawodowej nie spotkało się z osobą starszą - ofiarą przemocy domowej lub pielęgniarki nie były w stanie dokonać jednoznacznej oceny w tym zakresie. Odmienne rezultaty uzyskano w badaniu przeprowadzonym na grupie 295 pielęgniarek i położnych, uczestniczących w jednej z form kształcenia podyplomowego [11]: gdzie większość respondentek $(81,7 \%)$ oświadczyła, że podczas wykonywania swoich obowiązków służbowych miała kontakt $z$ ofiarami przemocy domowej, przy czym istotnie częściej tak twierdziły pielęgniarki niż położne $(\mathrm{p}<0,001)$. Ponadto niektóre pielęgniarki deklarowały, że miały taki kontakt więcej niż jeden raz. Inni autorzy również potwierdzają, większą niż w prezentowanym badaniu, częstotliwość kontaktu pielęgniarki z pacjentem-ofiarą przemocy domowej $[11,12,13]$. Należy przypuszczać, że na percepcję i przekonania badanej grupy pielęgniarek ma wpływ poziom ich edukacji. Wykształcenie wyższe posiada $1 / 4$ respondentek, 1/5 ma specjalizację a prawie 1/3 ukończyła kursy kwalifikacyjne. W badaniu wykazano związek między wykształceniem przed i podyplomowym, stażem pracy a opinią pielęgniarek odnośnie różnych aspektów profilaktyki przemocy domowej względem seniora. Można zaryzykować twierdzenie, że wykształcenie wyższe i/ lub uczestniczenie $\mathrm{w}$ formach kształcenia podyplomowego przekłada się na wiedzę i umiejętności niezbędne do realizowania profilaktyki przemocy domowej. Rezultaty niniejszego badania są zbieżne z wynikami autorów polskich $[1,14,15,16]$, którzy 
nie tylko potwierdzają związek między poziomem edukacji pielęgniarek a ich wiedzą dotyczącą przemocy domowej (tj. w zakresie jej form, objawów i narzędzi niezbędnych do realizacji profilaktyki), ale również podkreślają, że podstawą skutecznej interwencji i właściwego rozpoznania przemocy wobec seniorów jest edukacja i wsparcie informacyjne udzielane personelowi ochrony zdrowia.

W tym kontekście odmienną kwestię, stanowi motywacja i możliwości pielęgniarek do uczestniczenia $\mathrm{w}$ kształceniu podyplomowym. Wyniki prowadzonych od lat badań sugerują, że istotną przeszkodą w podnoszeniu kwalifikacji są koszty finansowe i brak znaczącego wpływu szkoleń na wynagrodzenie czy awans zawodowy pielęgniarek $[17,18,19]$. Zdaniem autorów w podstawowej opiece zdrowotnej powinny być wypracowane systemowe rozwiązania, które będą wspierały uczestnictwo pielęgniarek w szkoleniach z zakresu profilaktyki przemocy domowej, monitorowały te szkolenia i dostosowywały je do realiów pracy i życia pielęgniarek. Podobnie przedstawia się kwestia form optymalizujących realizację profilaktyki przemocy względem seniora. $\mathrm{W}$ prezentowanym badaniu, pielęgniarki w zasadzie ujawniły zapotrzebowanie na profesjonalne psychologiczne wsparcie. Osoby z mniejszym stażem zawodowym dostrzegły potrzebę szkoleń a te z większym na objęcie profesjonalną opieką psychologiczną zarówno ofiar, jak i pielęgniarek podejmujących interwencję. Ta kwestia również wymaga rozwiązań systemowych, omówienie których przekracza ramy niniejszego opracowania. W tym miejscu można jedynie podkreślić, że „pomagający sam wymaga pomocy”, co ma związek z profilaktyką w obszarze wypalenia zawodowego pielęgniarek.

\section{WNIOSKI}

1. Przemoc względem seniora jest problemem globalnym i narastającym.

2. Polskie pielęgniarki mają ustawowy obowiązek podejmowania interwencji w celu przeciwdziałania przemocy $\mathrm{w}$ rodzinie.

3. Pielęgniarki podstawowej opieki zdrowotnej nie są przygotowane do realizowania profilaktyki przemocy domowej względem seniora.

4. Istnieje potrzeba doskonalenia podyplomowego pielęgniarek podstawowej opieki zdrowotnej z zakresu profilaktyki przemocy domowej.

\section{REFERENCES/PIŚMIENNICTWO}

1. PillemerK, BurnesD, Riffin Cetal.Lachs MS. Elder Abuse:GlobalSituation, RiskFactors, and Prevention Strategies. The Gerontologist. 2016;56 (2):194-205. Cytowany dn. 25.04.2019r. Adres: https://www.ncbi.nlm.nih.gov/pubmed/26994260.

2. Yon Y, Mikton CHR, Gassoumis ZD. Elder abuse prevalence in community settings: a systematic review and meta-analysis. Lancet Glob Health. 2017;5 (2):147-156. Cytowany dn. 25.04.2019r. Adres: https://www.ncbi.nlm.nih.gov/ pubmed/28104184.

3. WHO (2017). Elder Abouse. Fact Sheet. Cytowany dn. 25.04.2019r. Adres: htpp:// www.who.int/medicentre/factsheets/fs357/en/.

4. Ustawa $z$ dnia 29 lipca 2005 r. o przeciwdziałaniu przemocy w rodzinie tekst ujednolicony (Dz. U. z 2005 r. nr 180, poz.1493, z 2009 r. nr 206, poz. 1589, z 2010 r. nr 28, poz. 146, nr 125, poz. 842, z 2011 r. nr 149, poz. 887).

5. Rozporządzenie Rady Ministrów z dnia 13 września 2011 r. w sprawie procedury „Niebieskiej Karty” oraz wzorów formularzy „Niebieska Karta” (Dz.U.z2010 r. nr 209, p0z. 1245).

6. Marcinowicz L. Rola pielęgniarki i położnej w sprawowaniu podstawowej opieki zdrowotnej. Zdr Pub i Zarządzanie. 2014;12(4): 352-357.

7. Korzeniowski K, Radkiewicz P. Przemoc w rodzinie wobec osób starszych i niepełnosprawnych. Raport z badania ogólnopolskiego 2015r. oraz badania porównawczego z lat 2009-2015. Warszawa: PAN. Cytowany dn. 04.06.2019r. Adres: https://www.gov.pl/documents/1048151/1060973/DPS.

8. Leszko M. Przejawy przemocy wobec osób starszych-definicja i występowanie [w:] Muszalik M, Kędziora-Kornatowska K, red. Pielęgnowanie pacjentów w starszym wieku. Warszawa: PZWL; 2018, s. 85-94.

9. Mordawska J. Zjawisko przemocy wobec osób starszych: skala problemu, czynniki ryzyka, metody przeciwdziałania [w:] Lewicka-Zelent A, Maciąg K, red. Osoba doświadczająca przemocy w świecie milczenia czy wsparcia?: refleksje interpersonalne. Lublin: TYGIEL; 2017, s.126-137

10. Śniegulska A. Przemoc wobec kobiet i osób starszych w środowisku rodziny. JoMS. 2016;4(31):101-124. Cytowany dn. 04.06.2019r. Adres: http://www.jomswsge.com/ Przemoc-wobec-kobiet-i-osob-starszych-nw-srodowisku-rodziny,80062,0,2.html.

11. Pawłowska-Muc AK, Łepecka-Klusek C, Stadnicka G i wsp. Problem przemocy domowej w praktyce zawodowej pielęgniarek i położnych. Journal of Education, Health and Sport. 2017;7(4):38-50. Cytowany dn. 04.06.2019r. Adres: http://ojs.ukw. edu.pl/index.php/johs/article/view/4309.

12. Łepecka-Klusek C, Pawłowska-Muc AK, Stadnicka G i wsp. Przemoc domowa wobec kobiet. Med Og Nauki Zdr. 2015; 21(4): 408-413.

13. Mirczak A, Tobiasz-Adamczyk B, Brzyski P i wsp. Rozpoznawanie zjawiska przemocy wobec osób starszych przez pielęgniarki środowiskowe. Probl Piel. 2011;19 (2): 202-209.

14. Austin G, Rinker J. Recognition and perception of elder abuse by prehospital and hospital-basedcare providers. Arch. Gerontol. Geriatr. 2009;48:110-115. Cytowany dn. 04.06.2019r. Adres: https://www.ncbi.nlm.nih.gov/pubmed/18160115.

15. Truong C, Burnes D, Alaggia $R$ et al. Disclosure among victims of elder abuse in healthcare settings: a missing piece in the overall effort toward detection. J Elder Abuse Negl. 2019;31 (2):181-190. Cytowany dn. 04.06.2019r. Adres: http://www. ncbi.nlm.nih.gov/pubmed/30880608.

16. Ahmed A, Choo WY, Othman $S$ et al. Understanding of elder abuse and neglect among health care professionals in Malaysia: An exploratory survey. J Elder Abuse Negl. 2016;28 (3):163-77. Cytowany dn. 04.06.2019r. Adres: https://www.ncbi.nlm. nih.gov/pubmed/27149412.

17. Bidzińska E, Sobczak M, Rakowska K. Motywy podwyższania wykształcenia przez pielęgniarki Wojewódzkiego Szpitala Zespolonego w Elblągu. Probl Piel. 2007;15 (2):197-2002.

18. Chmielewska E. Wpływ czynników motywujących na kształcenie podyplomowe pielęgniarek w Wojewódzkim Szpitalu Specjalistycznym w Legnicy. Zeszyty Naukowe Państwowej Wyższej Szkoły Zawodowej im. Witelona w Legnicy. 2012;8: 19-33. Cytowany dn. 12.11.2019r. Adres: http://cejsh.icm.edu.pl/cejsh/element/ bwmeta1.element.desklight-42782c8f-14e9-4265-84d7-27427c59ecd1.

19. Błazucka U, Ciślak H. Systemy motywacyjne w pracy pielęgniarki. Piel. Pol. 2015;3(57): 203-207. Cytowany dn. 12.11.2019r. Adres: http://www.pielegniarstw0. ump.edu.pl/uploads/2015/3/283_3_57_2015.pdf.

Manuscript received/Praca zgłoszona do czasopisma: 26.06.2019

Manuscript accepted/Praca zaakceptowana do druku: 06.11.2019

Translation/Tłumaczenie: Dorota Wawrzyniak, Centrum Nauczania Języków Obcych UM w Łodzi 